\title{
A HALOGATOTT REGIONALIZÁCIÓ MINT A TERÜLETI POLITIKA SAJÁTOSSÁGA AZ ÁTMENETBEN
}

\author{
(Deferred Regionalisation as the Feature of Regional Policy \\ in the Transition Period)
}

\section{RECHNITZER JÁNOS}

Kulcsszavak:

regionális politika regionalizáció EU csatlakozás területfejlesztés

A tanulmány célja bemutatni a magyar regionális politika fontosabb jellemzöit az átmenet idôszakában, összehasonlítani azt az Európai Unió regionalis politikájának elvárásaival, s mindezek alapján megha. tározni azokat a kihivásokat, amelyekkel szembe kell nézni a csatlakozás idöszakáig és talán még azután is a hazai területi politikában. Az értékelésnél kullön figyelmet szentel a dolgozat a regionalizációnak, a régiók kialakulásának, az azokat segítỏ és akadályozó tényezōknek.

Magyarországon a területi politika nem a rendszerváltozás terméke. A II. világháború után megindult a területi folyamatok állami alakítása, amely az adott kor politikai és gazdasági sajátosságait tükrözte. Az államszocializmus időszakának első összefogott területfejlesztési koncepciója 1971-ben jelent meg. Az Országos Településhálózat-fejlesztési Koncepció (OTK) célja a területileg kiegyenlített fejlődés biztosítása volt. A koncepció egy merev telepulléshálózat kialakítását szolgalmazta, ahol az erős hierarchiához kapcsolódtak a települések funkciói, amit az állam kívánt megteremteni. A hetvenes évek belsö politikai küzdelmeiben a centralizáció győzedelmeskedett, így a településhálózat alsóbb szintjének elemei fokozatosan elveszítették funkciójukat, s egyben nem részesülttek az állami tảmogatásból. A nyolcvanas évekre a területi különbségek kiéleződtek az országban, s a telepuilésállomány egyre nagyobb hányada leépült, kedvezötlen helyzetbe került. Az állami szintü területi politika csak tervezte az új beavatkozást, de a rendszerváltozás elsöpörte az ígéretesnek tünő kezdeményezéseket.

\section{Az átmenet szakaszai}

A rendszerváltozás után a kilencvenes évek elején a területi különbségek látványosan kiélezödtek Magyarországon. Közel másfélmillió munkahely szünt meg, a korábbi ipari központokban a termelés visszaesett, megkezdödött a gazdasági szerkezet átalakítása. Mindez sújtotta a munkaerőt kibocsátó térségeket is, így az ágazati válságok területi válsággá szélesedtek ki. A keleti piacok elvesztése a mezőgazdaságban szintén megingatta a korábbi szervezeti és termelési rendszert, melyet csak mélyítettek a tulajdonviszonyok visszarendezésére vonatkozó politikai döntések. Az ország nyugati térségei gyorsabban tudtak alkalmazkodni a változásokhoz, mivel ezekben a régiókban már a kilencvenes évek elején lezajlott a privatizáció, a 
Rechnitzer János: A halogatott regionalizáció mint a területi politika sajátossága az átmenetben.

Tér és Társadalom, 15. 2001. 2. 3-24. p.

gazdasági kapcsolatok Nyugat-Európa felé irányultak, s a külföldi tőke kedvezö telephelyi feltételeket talált (Enyedi 1996).

\section{A válságkezelö indulás}

A területi politika első szakaszát 1996-ig a válságkezelés jellemezte. Az állami források aránya és reálértéke a magas infláció miatt nem volt számottevő. Több kormányzati program került kidolgozásra és alkalmazásra az ország keleti (Szabolcs-Szatmár-Bereg megye 1991) és északkeleti (Borsod-Abaúj-Zemplén 1992, Nógrád 1992, Heves 1992) térségében a problémák kezelésére, illetve bizonyos alföldi megyék (Békés 1993, Hajdú-Bihar 1993, Jász-Nagykun-Szolnok 1994) infrastrukturális és szociális feszültségeinek enyhítésére. A kormányzati források döntően az infrastrukturális rendszerek kiépítését támogatták, így a gáz- és vízvezeték hálózatot (vízminőség védelme), illetve a közlekedési kapcsolatok javítását. A munkahelyek telepítése ezekben a régiókban nem járt sikerrel, mivel a megközelíthetőségük gyenge volt, illetve a munkaerö képezettsége alacsony szinten állt. Az ország többi részét nem fogta be ekkor a területi politika, pénzügyi erőforrásai mérsékeltek voltak, s nem rendelkezett sem átfogó koncepcióval, sem egységes intézményrendszerrel. Ugyanakkor az ország nyugati térségeiben és a gyorsabb szerkezet-megújításra képes új vagy éppen régi gazdasági központokban a gazdaságpolitika határozottan támogatta a szerkezet megújítását, különösen a külföldi tőke letelepedését, annak telephelyi feltételeinek kialakítását.

$\mathrm{Az}$ átmenet első idószakában több kezdeményezés történt egyrészt komplex fejlesztési program kidolgozására (Alföld-program), a speciális helyzetủ kistérségek, azaz a korábbi nehézipari körzetek (Ózd, Pécs-Komló, Záhony mint közlekedési csomópont) szerkezet átalakításának támogatására, továbbá PHARE segéllyel az elmaradott térségekben (Borsod-Abaúj-Zemplén, Nógrád, Szabolcs-Szatmár-Bereg) a programfinanszírozási rendszer, s ezzel egy új, kísérleti, komplex fejlesztési intézményi-finanszírozási modell bevezetésére.

Nagy jelentőségünek kell tekinteni az 1992-től megjelenő, majd lényegében 1995tôl évente változó ütemü, európai uniós forrást mobilizáló Területfejlesztés PHARE programokat (1. táblázat). Ezek a támogatások jelentősen hozzájárultak a területfejlesztés eszköz- és intézményrendszerének kialakításához, annak szakmai megalapozásához. Megkezdődött a piacgazdaság regionális politikájának és múködési modelljeinek tanulása, aminek eredményei megfigyelhetők voltak a kistérségi együttmủködések élénkülésében (1992-1994), a szerkezetátalakítást szolgáló integrált finanszírozási rendszer kidolgozásában (1995), a regionális szintủ tervezés és fejlesztés kialakításában (1996), a régiók fejlettségbeli különbségeinek mérséklésében (1997), és a felkészủlésben az elócsatlakozási programok (ISPA, SAPARD) fogadására (1998). Az országhatár menti együttműködések új fejlesztési kereteit nyújtó programok (1995-1999) döntően az osztrák-magyar határszakaszra koncentráltak, de érintették a szlovén, a szlovák és számottevö mértékben a román-magyar határrégiókat is, a területfejlesztés eddig ismeretlen dimenzióit nyitották meg a térségek elött. 
Rechnitzer János: A halogatott regionalizáció mint a területi politika sajátossága az átmenetben.

Tér és Társadalom, 15. 2001. 2. 3-24. p.

TÉT XV. évf. 2001 - 2

A halogatott regionalizáció ...

5

\section{TÁBLÁZAT}

A területfejlesztési PHARE programok regionális szerkezete (millió ECU)

(Regional Structure of Regional Development PHARE Programmes)

\begin{tabular}{|c|c|c|c|c|c|c|}
\hline Évek & $\begin{array}{l}\text { Országos } \\
\text { programok }\end{array}$ & $\begin{array}{c}\text { Észak- } \\
\text { Magyarország; } \\
\text { Észak-Alföld }\end{array}$ & $\begin{array}{l}\text { Dél - } \\
\text { Alföld }\end{array}$ & $\begin{array}{c}\text { Dél- } \\
\text { Dunántúl }\end{array}$ & $\begin{array}{l}\text { Nyugat- } \\
\text { Dunántúl }\end{array}$ & Összesen \\
\hline 1992 & 5,5 & 4,5 & & & & 10 \\
\hline 1995 & & 5 & & & & 5 \\
\hline 1996 & 2 & & 4 & 4 & & 10 \\
\hline 1997 & & 22 & 4 & 8 & & 34 \\
\hline 1998 & 7 & & & & & 7 \\
\hline $1995-1999 \mathrm{CBC}$ & & & 14 & & 50 & 64 \\
\hline Összesen & 14,5 & 31,5 & 22 & 12 & 50 & 1.30 \\
\hline Megoszlás (\%) & 11,1 & 24,2 & 17,0 & 9,2 & 38,5 & 100,0 \\
\hline
\end{tabular}

Forrás: Teriuletfejlesztési Országgyülési Beszámoló... 2000.

Az átmenet regionális politikája első szakaszának eredményei azonnal nem jelentkeztek. Nem sikerült gyorsan és látványosan megoldani a válságtérségekben felhalmozott gazdasági és társadalmi feszültségeket, az infrastrukturális fejlesztések (gáz, víz, telefonhálózat, közlekedési kapcsolatok javítása) ebben az időszakban még nem éreztették hatásukat, sőt egyenesen újabb terhet jelentettek az önkormányzatoknak, a lakosságnak. A területfejlesztés szereplöinek köre csak lassan formálódott, azok között az együttmüködés nem jött létre, a fejlesztési koncepcióknak és programoknak csak a kidolgozása történt meg, az intézményrendszer elemei megjelentek csupán, a területi menedzsment szakmai tapasztalatokkal nem rendelkezett, a sokat hangoztatott programfinanszírozás csak az elvekben létezett. Mindezek ellenére a válságtérségekben megkezdődött egy lassú elmozdulás a területi folyamatokban, mérséklődött a visszaesés, előkészítésre került egy-egy nagyobb beruházás, a legfontosabb regionális különbségeket jelentö tényezőkben (települési és termelési infrastruktúra) lévő látványos eltérések korrigálása megindult.

Az első idöszakban tehát a modern piacgazdaságok hagyományos regionális politikájának céljai és megoldási módjai domináltak, amiben döntöek a központi állami beavatkozások, a területi válságok alapvetö okainak (foglalkoztatási feszültségek, az alapvető infrastruktúra hiánya, a térségek gyenge elérhetősége) felszámolása, a helyi és regionális fejlesztési intézményrendszer (kistérségi, megyei szinten) létrehozása.

A regionális politika ebben az időszakban sem tudott integrálódni a gazdaságpolitikába, attól elvált, miközben maga a gazdaságpolitika a sikereit a válsággal nem küzdő, az átmenetet gyorsabban vagy sikeresebben feldolgozó térségekben kereste és találta meg. Az átmenet első szakaszában zajlottak a gazdasági szerkezetváltást alapvetően befolyásoló külföldi beruházások (Opel-Szentgotthárd, Suzuki- 
Rechnitzer János: A halogatott regionalizáció mint a területi politika sajátossága az átmenetben.

Tér és Társadalom, 15. 2001. 2. 3-24. p.

Esztergom, Audi-Györ, IBM-Székesfehérvár), folyt a privatizáció (2. táblázat). Különlegesség, hogy a privatizáció során csak egy-egy momentumban (reorganizációs programok - Ózd, Salgótarján; Területfejlesztési Alapnak történő privatizációs bevétel átadás, foglalkoztatási megkötések) bukkannak fel területi szempontok, nem volt összehangolt az állami tulajdon magánosítása és a területfejlesztés (Rechnitzer 1998a). A nyugati országrészbe települt külföldi befektetök számottevő közvetlen (gazdaságfejlesztést segítỏ alapok, központi és helyi adókedvezmények) és közvetett (kivásárlási feltételek) támogatásokat kaptak mind a kormányzattól, mind az önkormányzatoktól. A szükségszerủ dualitás jellemzi tehát ezt az időszakot. Az ország fejlettebb térségeiben a szerkezetváltást, s ezzel egy tartós növekedést lehetett elösegíteni, aminek következtében a gazdasági potenciálban és teljesitöképességben a meglévő regionális különbségek stabilitása újratermelödött. A válságtérségekben pedig a hagyományos regionális politika eszközeivel a felzárkózás feltételeinek a kiépítése indult meg, ezzel viszont megkezdödött a települési és térségi infrastrukturális ellátásban lévő területi különbségek mérséklésének elökészítése.

\section{TÁBLÁZAT}

A külföldi zöldmezös ipari beruházások területi megoszlása (Regional Distribution of Foreign Green Field Industrial Investments)

\begin{tabular}{lccc}
\hline \multirow{2}{*}{\multicolumn{1}{c}{ Térség }} & \multicolumn{2}{c}{$\begin{array}{c}\text { Az összes külföldi zöldmezós ipari } \\
\text { beruházásból való részesedés (\%) }\end{array}$} & A projektek száma (db) \\
\cline { 2 - 4 } & 1995 & 1996 & \\
\hline Észak-Dunántúl & 65,5 & 70 & 103 \\
Budapest, Pest megye & 20,5 & 17 & 50 \\
Alföld & 7 & 7 & 25 \\
Északkelet-Magyarország & 4 & 3,5 & 20 \\
Dél-Dunántúl & 3 & 2,5 & 22 \\
\hline
\end{tabular}

Forrás: Árva - Diczházi 1998.

Az elkezdett intézményesülés

Az 1996. évi XXI. törvény teszi le az új magyar területi politika alapjait, s ezzel megkezdődik az átmenet második szakasza. A törvény meghatározza a területfejlesztés célját, miszerint az ország mindegyik térségének biztosítani kell a szociális piacgazdaság kiépítését, a fenntartható fejlödés feltételeit, az innovációk térbeli terjedését, a föváros és vidék közötti különbségek mérséklését, a térszerkezet harmonikus fejlődését, s a térségi identitás megtartását és erősítését. A törvény felállítja a területfejlesztés egységes intézményrendszerét. Országos, regionális, megyei és kistérségi szinten definiálja a feladatokat, kijelöli a területfejlesztés döntéshozó szerveit, s egyben megnevezi a döntésben részt vevö szereplöket (önkormányzatok, kistérségek, kormányzati képviselet, gazdasági szféra, munkavállalói képviselet). A törvény a területfejlesztés eszközeit (Területfejlesztési Alap, majd Célelőirånyzat, jelenleg Vidékfejlesztési Célelöirányzat), sőt annak forrásait is meghatározza, késöbb külön jogszabályban intézkedik a területi egységek közötti elosztás elveiröl. 
Rechnitzer János: A halogatott regionalizáció mint a területi politika sajátossága az átmenetben.

Tér és Társadalom, 15. 2001. 2. 3-24. p.

A területfejlesztési törvény a megyei területfejlesztési tanácsok - amelyek a partnerség elve alapján szerveződtek - hatáskörébe utalja a decentralizált forrásokat. A megyei területfejlesztési tanácsoknak fejlesztési stratégiát és arra épulő programot kellett készíteniük, ami az alapját jelenti az állami források felhasználásának. A regionális szint létrehozását a törvény ebben az első változatában még a megyék szabad társulására bízta, s a régióknak csupán tervezési-statisztikai szerepet szánt, feladatait nem pontosította.

A törvény elfogadása után 1996-ban kezdődött meg az Országos Területfejlesztési Koncepció (OTK) kidolgozása, és azt az Országgyülés 1998 márciusában fogadta el (OGY. 35/1998. III. 20.). Az Országos Területfejlesztési Koncepció meghatározza a térszerkezet jövőbeli alakításának irányait, pontosítja a területi politika céljait és irányelveit, kijelöli a fejlesztés prioritásait, egyben meghatározza a beavatkozási térségeket, azok típusait, az eszköz- és intézményrendszer müködésére vonatkozó alapelveket definiálja. A koncepció az egyes ágazatok (környezetvédelem, humán infrastruktúra, agrárszféra, ipar, idegenforgalom, müszaki infrastruktúra) vonatkozásában is fejlesztési irányokat jelöl meg. S végül az európai uniós csatlakozás területi politikai intézkedéseit foglalja össze.

A magyar területi politika a területfejlesztési törvénnyel, valamint az országos, illetve a regionális és megyei szintủ területfejlesztési stratégiákkal egy egységes rendszer kiépítését kezdte meg, amely alapvetően épült az Európai Unió regionális politikájának elveire, gyakorlatára és intézményrendszerére. A törvény hatását, s ennek megfelelỏen a második szakaszt abban lehet értékelni, hogy

- felálltak országos, megyei és többségében kistérségi szinten a területfejlesztés intézményrendszerei,

- az intézményrendszer müködésbe lépett; egyrészt azok kialakították szervezeti rendszerüket, munkamódszereiket, másrészt megkezdỏdött megyei szinten a decentralizált források elosztása, a fejlesztési támogatási irányok és igények összevetése,

- a területfejlesztés szereplői között megindult a kommunikáció,

- elkezdődött a megyei és kistérségi területfejlesztési koncepciók kidolgozása, ami meghatározta a térségek jövőképét, a fejlesztés irányait, a szereplőkkel szembeni lehetséges elvárásokat,

- a területfejlesztéssel foglalkozó szakemberek és intézmények száma látványosan emelkedett, egyben megnőtt a társadalom érdeklődése és igénye a területi folyamatok iránt.

A második szakasz tehát a törvényi keretekbe foglalt területfejlesztési intézményrendszert teremtette meg, de ezzel nem egy időben, hanem később került elfogadásra az Országos Területfejlesztési Koncepció, amibe csak áttételesen épültek be a már elkészült megyei területfejlesztési koncepciók. A területfejlesztés szereplőinek együttmüködésében zavarok mutatkoztak, mivel nem volt átgondolt a tényleges döntéshozók körének kiválasztása (megyei jogú városok képviselete, kistérségek magas aránya), a kezdeti müködésben finanszírozási nehézségek feszültségeket teremtettek, de szakemberhiány éppen úgy jelentkezett, mint a szervezeti keretek 
Rechnitzer János: A halogatott regionalizáció mint a területi politika sajátossága az átmenetben.

Tér és Társadalom, 15. 2001. 2. 3-24. p.

tisztázatlansága. A decentralizált területfejlesztési források mérsékelt volta miatt, valamint az el nem készült megyei területfejlesztési koncepciók hiánya következtében a fejlesztési támogatások elaprózódtak, azok érzékelhető fejlesztő hatást nem voltak képesek az első időszakban kiváltani. A törvény a megyei területfejlesztési tanácsban a kistérségek részvételét a statisztikai körzetek számához (megyénként különböző, országosan 150 egység) kötötte, miközben ennél több kistérségi önkormányzati társulás (megyénként nagy szórást mutat, országosan 217 egység ${ }^{1}$ ) jött létre, így a kimondottan alulról, település szintről építkező szervezetek vagy kénytelenek voltak átalakulni, vagy a képviseletüket belső egyezségekkel megoldani. A regionális szintet a törvény első változata csak ajánlotta, s azt a megyék szabad társulására bízta. Ugyan az Országos Területfejlesztési Koncepcióban kívánatos tervezési-statisztikai régiók felvázolásra kerültek, alapegységnek a megyét és nem egy-egy nagycentrum lehetséges hatásterületét választva. A regionális intézményrendszer jóval lassabban és döcögve épült ki, a szereplök regionális identitása szinte nem is mérhető, nagytérségi együttmüködések, kapcsolatok nehezen szervezhetők (Nárai 2000).

Az átmenet második szakaszában tehát törvényi szabályozást nyert a regionális politika, meghatározásra került annak intézményrendszere. Ezeket a kereteket az Európai Unió regionális politikájának alapelvei és működési rendszere határozta meg. Ugyan még feluulről, az intézményi rendszer meghatározása útján, de már a fontosabb területfejlesztési szereplők aktivizálásával elkezdődött a területi egységek, így döntỏen a megyék és a kistérségek fejlesztésorientált építkezése. A fejlesztési stratégiákban és a későbbi programban már több eleme megjelenik a posztmodern regionális politikáknak, így az endogén források feltárása és aktivizálása, a szereplői körök kiszélesítése, azok együttmúködése, a helyi kezdeményezések felkarolása, az innovációs környezet alakítása, a területi egységek versenyképességének fokozása.

$\mathrm{Az}$ intézményesüléssel változatlanul nem volt képes a területi politika az ágazati fejlesztések összehangolására, így a területfejlesztés alárendelt szerepe továbbra is megmaradt. A lopakodó decentralizáció jellemzi a második szakaszt, hiszen bizonyos elvek alapján leosztásra kerülnek területfejlesztési források a megyékhez, de más ágazati forrásokban csak áttételesen jelenik meg a területi szemlélet. Jellemző a decentralizációra, hogy a felhasználást rendeletben szabályozzák, így a megyék csak a kijelölt, országosan meghatározott célra fordíthatták a forrásaikat, az eltérésekhez, azaz a sajátos területi célok támogatásához miniszteri engedélyre volt szükség.

\section{Az akadozó felkészülés}

A területfejlesztési törvény megújítása 1999 októberében történt meg (1999. évi XCII. törvény), s ezzel a hazai regionális politikában az átmenet a harmadik szakaszába lépett. A módosítás célja egyrészt a regionális szint erösitése (a korábbi regionális kezdeményezéseket a törvény megerősítette, így hét tervezési-statisztikai régiót határolt el), másrészt a törvényességi ellenörzés érvényesitése, $\mathrm{s}$ végül a 
Rechnitzer János: A halogatott regionalizáció mint a területi politika sajátossága az átmenetben.

Tér és Társadalom, 15. 2001. 2. 3-24. p.

TÉT XV. évf. 2001 - 2

A halogatott regionalizáció ...

9

megváltozott politikai értékrend alapján a területfejlesztés szereplöi képviseletének átalakitása az intézményrendszerben. Az előremutató módosítás legtöbb vitát kiváltott pontjai éppen a partnerségről szóltak. A gazdasági kamarák, illetve a munkavállalói érdekképviselet és a kistérségek megfelelő (teljes jogú) képviseletet kaptak a korábbi megyei és regionális területfejlesztési tanácsokban. Az elfogadott módosítás a gazdasági kamarák és a munkavállalói érdekképviselői szervezetek szerepét visszaszorítja, hiszen azok csak tanácskozási joggal rendelkezhetnek, illetve a kistérségi képviselők száma is csökkent, ami a területfejlesztés alsó, de legaktívabb szintjének szerepét mérsékelte. Viszont nőtt a kormányzati képviselet a minisztériumok, illetve egyes dekoncentrált szervek teljes jogú tagsága révén, de rendeződött a megyei jogú városok helyzete is.

A területfejlesztési törvény módosítása 1999-ben a régiók alapvető helyzetében változást hozott. Nem önkéntes, hanem kötelező tervezési-statisztikai régiók jöttek létre, amelyeknek szervezete (intézménye) és mérsékelt erőforrása lett, s a megyei szintü új politikai elit felismerte az ebben a rendszerben rejlő lehetỏségeket. Megindult a verseny a régiók székhelyeiért, a regionális szervezetek vezetéséért. A versenyben csendes határozottsággal részt vállaltak a hatalmon lévő politikai pártok, soot újabb dekoncentrált szervezetek létrehozásával és azok regionális hálózatának telepítésével igyekeztek megtörni a korábbi nagyvárosok, valós régióközpontok kivívott pozícióit.

Elkezdődött tehát a verseny a régiókért. Hiszen itt egy légüres tér volt, amibe be lehetett hatolni, ahol újabb politikai tőkét lehetett kovácsolni, s mindeközben a rendszer még nem lezárt, nem alakultak ki a régiók funkciói, nem ismertek a mozgásterek, a lehetőségek. Az állami szint rászervez a régiókra, hiszen részben az új dekoncentrált szervezeteket már ebben a területi dimenzióban állítja fel, illetve a politikai pártfogoltjainak funkciót, képviseletet ad a regionális fejlesztési tanácsokban, bár ezzel a kapcsolatot a kỏzponti intézményekkel erỏsen lazítja.

Megkezdödött a régiókban a tervezés, elkészülnek a koncepciók és folyamatba került a programozás, s 2001-ben már regionális szinten fejlesztési források is decentralizációra kerültek, ami aztán növelheti az érdeklödést a regionális szervezetek iránt, vagy azok fennmaradását szolgálhatja.

Ugyan zavar keletkezett a kỏzponti kormányzat szintjén a regionális politika irányításában. A területfejlesztésért felelős FVM fokozatosan elveszti befolyását, új centrumok alakulnak ki (MEH, GM, PHARE Minisztérium), amelyek nem mủkődnek egyuitt, párhuzamos szervezeti rendszereket hoznak ${ }^{2}$ létre, amivel már nem a régiót erósítik, hanem ismét az ágazati szemléletet sugallják, ezzel területi szintre is lenyomják a permanens rivalizálódást, ami tovább csorbítja a partnerséget. A területfejlesztés szereplőinek ezek az intézkedések a régió leértékelését, vagy el nem fogadását üzenik.

Zavar a régiók szintjén is van bỏven, aminek oka alapvetően, hogy nem tisztázott a szerepük. De nem egyértelmü a gazda sem, azaz mihez és kihez tartoznak, mit és kit szolgálnak. A regionális területfejlesztési tanács nem fogja át a régió területfejlesztési szereplőit, azoknak csak a kormányzati tényezőit tömöríti, a nem kormány- 
Rechnitzer János: A halogatott regionalizáció mint a területi politika sajátossága az átmenetben.

Tér és Társadalom, 15. 2001. 2. 3-24. p.

zati szektort elhanyagolja, azzal lényegében nem törődik. Nem kellő tehát a képviselete a gazdaságnak, azt nem tudja megszólaltatni a régió sem programokkal, sem pedig forrásokkal.

A kidolgozott fejlesztési programokban a gazdaság fejlesztésének általános keretei kerülnek meghatározásra, olyan piaci elemek, amire valós ráhatással nem tud lenni egyetlen régió, $\mathrm{s}$ annak testülete sem (A regionális fejlesztési koncepciók... 1999). A gazdasági infrastruktúra-fejlesztés az egyik általánosan támogatott cél, ami lényegében az önkormányzatoknál valósul meg. Itt szervezik az ipari parkokat, az inkubátor központokat, az innovációs centrumokat, ezeket a régió segítheti ugyan valamiféle anyagi hozzájárulással, de befolyásolni, hogy hol mennyi, milyen típusú szervezet jöjjön létre már nincs módja. Ennek az a következménye, hogy például szinte minden város ipari parkot kíván létesíteni, $s$ erre irányuló lépéseit megteszi (szervezet, terület kijelölés, program, hírverés), holott regionális szinten kisebb számú, egymással megfelelő kapcsolatban álló egységekre lenne szükség az ipar, szolgáltatás fogadására, fejlesztésére. Hasonlóan program-elemként jelenik meg a közkedvelt kis- és középvállalkozások múködési feltételeinek javítása, ami nagyon általános, s csak kimondottan a helyi gazdaságfejlesztés viszonylatában értelmezhető. Vagy a turizmusfejlesztéshez, mint a regionális gazdaságok kitörési pontjához a regionális szervezetek nem rendelkeznek eröforrásokkal, így céljaik szépen hangzanak, de energiájuk egy-egy ismertető kiadvány megjelentetésére marad csupán.

Számos más fejlesztési célt kezdeményeznek a regionális tanácsok, így a humáneröforrások, a környezetvédelem, a közlekedés, a vidékfejlesztés, vagy éppen az európai uniós felkészülés területén, de találunk példákat a szociális helyzet javítására, az energia gondok megoldására, a határ menti regionális együuttmüködések szélesítésére is. Emellett megfigyelhetö, hogy a regionális tanácsok minden olyan feladatot fogadnak, amelyet az ágazatok számukra le kívánnak osztani, hiszen ebben az elfogadottságukat vélik felismerni. Ennek aztán a következménye, hogy regionális szinten lassan minden szervezödik, nem lehet tisztán látni, egy szerepkeresés, funkciógyửjtés figyelhető meg, ami leköti az amúgy is kisszámú menedzsmentet, ahelyett, hogy a tényleges regionális ügyekkel foglalkoznának.

Hasonló jellemzöket tudunk mondani a tervezésröl (A területfejlesztési koncepciók és programok... 2000). Egy permanens tervezés és programalkotás jellemzi a régiókat, azaz állandóan a jövőt készítik elö, újabb és újabb programokat vagy azok egyes fejezeteit dolgozzák ki. Az akciók, azaz a programok megvalósítása még nem kezdödött el, hiszen ehhez még nem rendelkeznek eröforrásokkal, illetve a partnereket nem voltak képesek aktivizálni. A végeláthatatlan tervezést csak fokozza, hogy részesei a nemzeti fejlesztési tervek kidolgozásának, abba bevonják a régiókat, ám nem tudni, hogy éppen mit közvetítenek. A terveik és programjaik regionális elfogadottsága alapvetỏen kérdéses, hiszen nem egyértelmü, hogy ezek a dokumentumok kiket képviselnek, a területfejlesztés mely szereplöinek érdekeit és jövőbeli cselekvési akaratait jelenítik meg. A tervezők elképzelései, szándékai ezek a 
Rechnitzer János: A halogatott regionalizáció mint a területi politika sajátossága az átmenetben.

Tér és Társadalom, 15. 2001. 2. 3-24. p.

TÉT XV. évf. 2001 @ 2

A halogatott regionalizáció ...

11

koncepciók és programok, vagy a régió közszférájának (nagyobb önkormányzatok, dekoncentrált szervezetek, erősebb - rutinosabb - érdekérvényesítő érdekképviseletek) igényei, netalántán magának a területfejlesztés fontosabb szereplöinek elvárásai, nos ez nem egyértelmü, nem meghatározható.

A különféle jövő elképzelések társadalmi ismertsége, befogadása szintén kérdéses. A régiók nem, vagy nagyon ritkán jelennek meg a helyi és a területi (megyei) médiákban, a lakosság nem érti, nem tudja, hogy mi a régió és kinek szolgál, miként lehet azt elérni, miben nyújt mást, többet, esetleg újat, mint a helyi önkormányzat vagy éppen a megye (ugyan ezen utóbbi ismertsége és elfogadottsága is igencsak kérdéses). A régióknak, azok testületeinek elfogadottsága a lakosság, illetve a jelentösebb területfejlesztési szereplök között gyenge, mondhatni nem kimutatható.

$\mathrm{Az}$ átmenet regionális politikája harmadik szakaszában a súlypont a régiókra helyezödött. De a politikai elitnek nem volt egyértelmü és határozott elképzelése sem a régióról, sem annak valós funkcióiról. Érezték a hatalom szereplői, hogy sziukség van erre az intézményre, ezt üzenték az áhított európai folyamatok, ezt sugallta az Európai Unió, s ezt közvetítette a halogatott közigazgatási reform.

Ám nem tisztázódott még a rendszerváltozás után 12 évvel, hogy a magyar állam fejlödése milyen új irányt vesz; azaz egy jóléti, gondoskodó állam, vagy az alulról építkező, szervező állam lehetséges útjai közül választ-e. Ez a választás nem egy politikai párt vagy pártok tömörülésének döntése csupán, hanem össztársadalmi kérdés, a nemzetstratégiának alapvetö eleme, amihez közmegegyezésre van szükség. A kilencvenes évek nem erröl az egységröl szóltak, hiszen a rendszerváltozás hatalmas terheit, mind a gazdaságban, mind a társadalomban, s mindezek alapján a regionális folyamatokban és szerkezetekben le kellett küzdeni. Ez a folyamat lassan a végéhez közeledik, hiszen a gazdaság fejlődése megindult, a munkanélküliség ennek függvényében csökken, a költségvetési bevételek növekszenek, az ország nemzetközi pozíciói és megítélése kedvezỏen alakult. Egyre több feltétel adott ahhoz, hogy megfogalmazódjék egy új modell, egy új szereposztás az államon belül. Ez a modell nem lehet más, mint a decentralizációra épülő regionalizáció.

\section{Hogyan tovább regionális politika? Az alapelvek és érvényesülésük}

Az Európai Unió regionális politikájának alapelvei nemcsak ismertek voltak a hazai területi politika alakítói elött, hanem azok érvényesülése szintén döntő szempont, iránytüként szerepelt. Tekintsük át ezeket az elveket, s rajtuk keresztül tegyünk ajánlásokat a regionális politika megújítására, annak nélkülözhetetlen fejlesztésére, vagy talán szerepének helyreállítására, visszarendezésére. 
Rechnitzer János: A halogatott regionalizáció mint a területi politika sajátossága az átmenetben.

Tér és Társadalom, 15. 2001. 2. 3-24. p.

12 Rechnitzer János

TÉT XV. évf. 2001 m 2

\section{Szubszidiaritás}

A döntéseket és a végrehajtást arra a területi szintre kell helyezni, amely a legnagyobb átlátással és kompetenciával rendelkezik a feladat megvalósításához. A magasabb szintủ szerv nem intézkedhet olyan esetben, amikor az adott célkitüzést eredménnyel az alacsonyabb szinten el lehet érni. A szubszidiaritás és decentralizáció az elsődleges alapelve az Unió regionális politikájának, hiszen ezzel nemcsak azt érheti el, hogy a helyi szintek felelössége növekedjék, hanem azt is, hogy minél több lokális akarat és elképzelés (igény), s egyben eröforrás jelenjen meg, kerüljön aktivizálásra. A helyi, térségi kompetencia erösítése persze azért fontos, hogy a nemzeti szint vagy szintek szerepe mérséklödjön, lényegében azok átléphetök legyenek. A fejlesztési programokban a területfejlesztés tényleges egységei kerüljenek egymással közvetlen kapcsolatba. A nemzeti szint majd egy másik összefüggésben, a finanszírozásban jelenjen meg, és ott segítse a területi egységeket, azok céljainak megvalósítását.

A szubszidiaritás hazai érvényesülésében az önkormányzati törvénynek nagy jelentősége volt, hiszen a létre jött több mint 3100 önkormányzat egyben a területfejlesztés egyik szereplöje. Az önkormányzatok feladatai fokozatosan bővültek, miközben az azokhoz rendelt források aránya ezzel párhuzamosan nem nött. A helyi gazdaságfejlesztési programok elkezdődtek, ezek egyik forrása éppen a helyi adók, illetve az önkormányzati vagyon értékesítése. A helyi fejlesztési források nagy különbséget mutatnak, ám a szubszidiaritás jelentős csorbítása lenne, ha ezeknek valamiféle központosítása megtörténne.

Magyarország állami berendezkedését az elmúlt évszázadokban a centralizáció jellemezte, ennek a központosításnak a tartalékai napjainkra lassan kiürülnek. A tartalékok ugyan még több évig, netalántán egy évtizedig növekedési forrást nyújthatnak, de azok tartósan nem újíthatók meg, a jövőhöz innen már nem lehet innovációs lendületet nyerni.

Egyértelmű, hogy határozott - és a jelenleginél még határozottabb - központi beavatkozásra van szükség a közlekedési hálózat fejlesztésében, így az autópályák kiépítésében, a vasúti közlekedés megújításában. Hiszen itt az elmaradás egyre nagyobb, a térségek fejlesztésénél ma már ezeknek az infrastrukturális rendszereknek a hiánya, nem kellő kapacitású kiépültsége okozza a legnagyobb korlátot. Hasonlóan a környezetvédelemhez, amihez szintén koncentrált állami beavatkozás szükséges, mivel csak jelentös beruházásokkal lehet a környezet állapotát javítani, annak minőségét jobbítani. Vagy a kutatás-fejlesztés és a felsőoktatás intézményi kereteinek megújitása szintén állami forrást igényel, nem lehet e szektor fejlesztését a gazdasághoz kötni, vagy éppen a helyi, regionális szervezetekhez. Számos, a gazdasághoz és egyben a területi fejlődéshez közvetlenül vagy közvetetten kapcsolódó tevékenység és intézmény megújításában a központi államnak számottevő, mondhatni meghatározó szerepe lesz a jövőben.

Mindez azonban nem azt jelenti, hogy nincs értelme a decentralizációra épülö regionalizációnak ${ }^{3}$. Egyik oldalon, döntően a nagyrendszerek vonatkozásában a 
Rechnitzer János: A halogatott regionalizáció mint a területi politika sajátossága az átmenetben.

Tér és Társadalom, 15. 2001. 2. 3-24. p.

TÉT XV. évf. 2001 - 2

A halogatott regionalizáció ...

13

koncentrált központi szintủ fejlesztések kívánatosak, a másik oldalon pedig a decentralizált, a területi adottságokat a legteljesebben érvényesítő, s éppen a térségi akaratokat megjelenítő fejlesztéspolitika.

A regionális szintre lehet telepíteni számos, éppen a térségi fejlödésre hatást gyakorló fejlesztések támogatását, illetve azok kereteinek összehangolását. Világos, hogy a gazdaság folyamataiba nem lehet beavatkozni, nem is érdemes, de hasznos és kívánatos orientálni a gazdasági szereplőket. Ehhez a régió gazdasági és társadalmi környezetét lehet és kell formálni, részben bizonyos intézményi keretek kialakításának ösztönzésével, részben pedig a térségi adottságok, mondhatni erőforrások kínálatának mennyiségi és minőségi fejlesztésével. Nincs még szakmai megegyezés arról, hogy regionális szinten milyen fejlesztések kívánatosak. Az biztos, hogy a régió szintjére alulról, azaz a települések szintjéröl és felülröl, azaz az állami szintről is egyre több feladatot lehet és kell telepíteni, persze megfelelő forrásokkal együtt.

Felsorolásszerủen álljon itt az alábbiakban néhány területfejlesztési komponens, amiben a regionális szint kompetenciája a jövőben meghatározó lehet:

Gazdaságfejlesztés

- Gazdasági infrastruktúra létesítményei: ipari-szolgáltató park, innovációs központ, technológiai transzfer központ, vállalkozási övezetek, rehabilitációt igénylö ipari területek, bevásárló és szórakoztató központok, logisztikai, kiállítási és vásárközpontok,

- térségi gazdaságfejlesztést szolgáló szervezetek, intézmények alapítása, alapításban való részvétel: vállalkozási központok (pl. az MVA megyei alapítványainak regionalizálása), kockázati tőke társaságok (pl. az MBF regionális szervezetei), gazdaságfejlesztési tanácsadás (befektetést, fejlesztést, együttmüködést szervező intézmények), innovációs tanácsadás, gazdasági kiállítások és vásárok szervezése, telephely marketing, befektetési kataszter,

- innovatív vállalkozások támogatása: kis- és középvállalkozások, amelyek új technológiai bevezetést (pl. a régióban eddig nem mủködő tevékenység), vagy a meglévő technológiák radikális megújítását (pl. a régióban müködő, de nem sikeres vállalkozás vagy beszállítói rendszerek kiépítését) tüzik célul, a foglalkoztatottak száma 20 fönél kevesebb,

- vállalkozásalapítás, vagy a meglévő, de egyben dinamikus vállalkozások fejlesztése (20 fönél nagyobb), lehetséges támogatási kritériumok: új telephelyek kialakítása a régióban; a régión belüli hálózat fejlesztés; ráfüződés a nagyvállalatokra, vidéki térségekben a termelö, feldolgozó, szolgáltató tevékenység telepítése,

- régió specifikus termékek elő́llítása, azok előállításának megújítása (pl. néhány terméket a régió saját terméknek tekint, ezek fejlesztését szolgáló beruházások, akciók a régió hatáskörében lehetnek),

- térségi turizmus fejlesztése: a nagyobb területi egységet érintő, több attrakciós pontot magában foglaló, nem csupán lokális vagy kistérségi turisztikai és ide- 
Rechnitzer János: A halogatott regionalizáció mint a területi politika sajátossága az átmenetben.

Tér és Társadalom, 15. 2001. 2. 3-24. p.

14 Rechnitzer János

TÉT XV. évf. 2001 @ 2

genforgalmi akciók (pl. kastély turizmus, kerékpáros turizmus, kombinált, egymásra épülỏ kínálatok: termálturizmus, kulturális turizmus, falusi turizmus).

Humánerőforrások

- Felsőfokú oktatás és képzés, az intézmények fejlesztése, a regionális szintủ egyetemi és föiskolai hálózat kiépítése és fejlesztése (pl. graduális, posztgraduális, posztszekunderi, doktori programok összehangolt indítása, együttes fejlesztése),

- kutatás-fejlesztés intézményrendszereinek fejlesztése, a kutatás-fejlesztés szervezésének és támogatásának regionális intézmény- és eszközrendszere (pl. regionális innovációs stratégiák),

- a felnőtt képzés regionális hálózatának müködtetése,

- az át- és továbbképzés hálózat folyamatos figyelemmel kísérése, hálózati jellegének erösítése,

- a speciális - döntöen a régióra vonatkozó sajátos ismereteket nyújtó középfokú intézmények müködtetése és fejlesztése,

- a speciális szociális gondoskodást nyújtó intézmények müködtetése,

- a magas szintủ (klinikai) egészségügyi ellátást végző intézmények vagy hálózatok müködtetése és fejlesztése.

Kultúra

- A régióban található történelmi és müemléki értékek védelme, gondozása,

- a régió arculatát meghatározó kulturális akciók (pl. fesztiválok), programok, intézmények támogatása.

Környezet

- A környezet és természetvédelem,

- felszín alatti és feletti vizek védelme,

- tájrehabilitáció,

- térségi hulladékkezelés és feldolgozás,

- táji és természeti eröforrások környezetbarát hasznosításának támogatása.

Vonalas infrastruktúra

- Az autópályák és autóutak vonalvezetésének véleményezése,

- két számjegyủ közutak vonalvezetésének meghatározása,

- vasútvonal vezetésének és felújításának véleményezése,

- regionális repülötér telepítése,

- folyami kikötők telepítése,

- több funkciós közlekedési és szállítási csomópontok telepítésének véleményezése és támogatása, (RO-RO, RO-LA),

- régióközi kapcsolatokat jelentö közlekedési mütárgyak telepítésének véleményezése (hidak, kompok, elkerülő szakaszok, hálózati összeköttetések stb.),

- nemzetközi és országos energetikai rendszerek vonalvezetésének véleményezése,

- nemzetközi és országos kommunikációs rendszerek vonalvezetésének és átadópontjai elhelyezésének véleményezése. 
Rechnitzer János: A halogatott regionalizáció mint a területi politika sajátossága az átmenetben.

Tér és Társadalom, 15. 2001. 2. 3-24. p.

TÉT XV. évf. 2001 @ 2

A halogatott regionalizáció ...

15

Létesítmény infrastruktúra

- Adatfeldolgozás és kommunikációs központok telepítése,

- elektronikus tömegtájékoztatási és kommunikációs eszközök (rádió, televízió) telepítése, azok lokális rendszerei összekapcsolásának támogatása,

- nemzetközi és országos hatáskörü intézmények telepítésének véleményezése,

- regionális hatáskörủ intézmények telepítése.

\section{Térségszervezés}

- A vidékfejlesztési programok gondozása,

- várossá válás és település önállósulás véleményezése,

- regionális hatással is rendelkező városi funkciók bővítésének és telepítésének véleményezése,

- interregionális (több régiót érintö) együttmúködések szervezése,

- multiregionális (országhatáron átnyúló) térségi együttmúködések szervezése és müködtetése,

- regionális hatással is rendelkező országhatáron átnyúló település-településkistérség együttmüködések véleményezése,

- térségarculat és ismertség alakítását szolgáló akciók és programok támogatása,

- regionális információs, tájékoztatási és marketing rendszer mủködtetése,

- a régió társadalmi-gazdasági-környezeti állapotát regisztráló (A régió helyzete) éves elemzések összeállítása.

A politikai regionalizáció, azaz politikai kompetenciával (pl. választott képviselet, döntési és közigazgatási hatáskörök) rendelkezö régiók létrehozása a politikai elit megegyezésétől függ. Ennek feltételeit ma nehéz megbecsülni, bár számos tényező miatt, így az alkotmány módosítása, a választási rendszer átalakítása, az önkormányzati törvény megújítása miatt kicsi a valószínüsége a politikai kompetenciával rendelkező régiók gyors, belátható időn belüli felállításának. Az európai uniós csatlakozás egyre közelebb kerül, vélhetően ebben a tervidőszakban (2000-2006) az új csatlakozó országok csak kiegészítő támogatásokat kapnak, nem történik meg a tagországok között a források újraosztása, azok módosítása. Az igazi küzdelem 2006-tól, illetve annak előkészittésétöl, 2004-töl indul. Célszerü lenne, ha Magyarországon a 2006-tól kezdődő európai uniós tervidőszakra már életképes régiók múködnének. Nincs sok halogatni való idő hátra - lényegében egy új kormányzati ciklus -, ebben kell elrendezni a régiók ügyét, s azokat a területfejlesztés és ezzel a gazdaság és társadalomfejlesztés meghatározó szereplöjévé tenni. A politikai regionalizáció csak ez után történhet meg, vagy ha a területfejlesztést bölcsen szervező régiók rendszere müködik, talán nincs is rá szükség. A magyar modernizáció egy újabb szakaszba érkezett, a kérdés tehát az, hogy képesek vagyunk-e a decentralizáció révén elindítani a regionalizációt, vagy minden marad a régiben. Ezt a következö, egyre jobban gyorsuló évek fogják eldönteni. 
Rechnitzer János: A halogatott regionalizáció mint a területi politika sajátossága az átmenetben.

Tér és Társadalom, 15. 2001. 2. 3-24. p.

\section{Partnerség}

Együttmúködés a célkitúzésektől az intézkedések megvalósításáig, a különféle szintek (EU, ország, terület-régió, település) és szereplők (kormányzat, önkormányzatok, gazdasági szervezetek, munkavállalók, nonprofit szektor) között. A partnerség elve arra épül, hogy a területi egységek, azaz a régiók és a települések mủködése, fejlesztése csak akkor valósulhat meg - s egyben akkor érvényesülhet a szubszidiaritás elve -, ha a szereplök folyamatosan és rendszeresen együttmüködnek, közöttük célorientált kapcsolatok alakulnak ki. Az együttmủködésnek vertikális metszete, hogy az Unió, a tagországok, azok régiói, annak egységei, a települések a célkitüzéseket és azokra épüló terveiket az ottani szereplök (gazdasági, társadalmi) bevonásával közösen dolgozzák ki. Az alsó szint kezdeményező szerepe érvényesüljön, míg magasabb szinten már a regionális és a nemzeti funkciókból következő orientáció és koordináció jelenik meg. Fontos metszete a vertikális együttműködésnek még a térségi kapcsolatok, azaz a régió és régió, valamint a település-település viszonylatok is (pl. transznacionális térségi együttmüködések, határ menti térségek együttes fejlesztése, s ezekben a vonatkozásokban a települések vagy a kisebb térségek együttes fejlesztése, közös jövőbeli kapcsolatok kidolgozása).

A horizontális együttmüködés azt jelenti, hogy a helyi, térségi szereplök együtt alakítsák ki jövőképüket, annak megvalósítási programjait és azok intézkedéseit, nem beszélve az ellenörzésröl, az eredmények regisztrálásáról. Az aktív vertikális és horizontális együttmüködés egyik fókuszpontja éppen a fejlesztést fogadó régió lehet. Hiszen közvetithet a résztvevők között (elképzelések gondozása, azok kidolgozása, fejlesztési koncepció ápolása), verseny semleges lehet (nem gazdasági egység, illetve a település érdekeket semlegesítheti), ugyanakkor döntnökként is felléphet a megvalósítók között (regionális közbeszerzés, vagy a fejlesztések elosztása), éppen a közösségi érdekek (választott képviselet esetén beszámolási kötelezettséggel) határozott érvényesítésével.

A magyar regionális politika kísérletet tesz a partner elvének alkalmazására. A horizontális együttmüködés jelei kimutathatók, hiszen a területfejlesztés szereplőinek egyre nagyobb köre vesz részt a fejlesztési koncepciók és programok kidolgozásában. A partnerség elve a kistérségi szinten jól kimutatható, majd egyre feljebb haladva a területi szinteken, már tényleges hatásának erőssége csökken. Megyei szinten a kommunikáció még határozott a szereplők között, de már regionális szinten ez gyenge, erötlen. $\mathrm{S}$ végül országosan a fejlesztéseknél az ágazati dominancia érvényesül egyértelmüen a területivel szemben, így például az Országos Területfejlesztés Tanács még tényleges funkcióját nem találta meg, illetve a nemzeti fejlesztési tervekben a regionális összefüggések háttérbe szorultak. A regionális politika nagyobb és határozottabb decentralizációt kívản, míg az ágazati szemlélet a centralizációt követeli meg. Tapasztalható a nyugat-európai országokban (Horváth 1998), hogy amint nő a regionális politika befolyása, úgy 
Rechnitzer János: A halogatott regionalizáció mint a területi politika sajátossága az átmenetben.

Tér és Társadalom, 15. 2001. 2. 3-24. p.

csökken a centralizáció mértéke, s ezzel együtt a területi szinten az együttmüködés, a szereplök egymásra találása is jól kimutatható.

Kormányzati szinten az elmúlt tíz esztendőben bizonytalan és egyben súlytalan volt a területfejlesztés helye, de szerepe is. Hol egy gyenge (1990-1998 között a környezetvédelemnek), hol kvázi erös, majd súlytalanná vált (1998-tól földmüvelésủgy, vidékfejlesztés) tárcához volt rendelve a regionális politika irányítása. Ugyanakkor a területi folyamatok alakitásában, s ezzel együtt magára a regionális politikára több tárca is együttesen, más és más összefüggésben, de hatott. Így a belügy az önkormányzatokra; a közlekedés a hálózati infrastruktúrákra; az ipari, majd a gazdasági minisztérium a termeló infrastruktúrára, illetve az átfogó gazdaságfejlesztésre; a munkaügy a szociális és foglalkoztatás politikára. A tárcák múködését a partnerség nem jellemezte, $s$ megfigyelhetó, hogy a politikai hangsúlyok változásával a regionális politika súlypontjai is áthelyeződnek, ami megzavarta a központi kormányzattól még erösen függó területi fejlesztő intézményrendszert, annak folyamatos mükơdését.

A partnerségnél kell megemlíteni a nyilvánosságot, illetve a lakosság területi aktivitását, valamint az identitását (Szörényiné Kukorelli 1998). A regionális szintú identitás nem kimutatható, még megyei szinten sem regisztrálhatók jelentös kötődések, a lakosság erösen azonosul a településéhez. A kistérségi vonatkozásban ismerhető még fel valamiféle kapcsolódás a fejlesztési célokhoz, azok megvalósításához. A „csinált-régiók” ma még nem képviselik az azonosulás tereit, így lényegében intézményi elemnek tekinthetők, amelyek mind a földrajzi lehatárolásban, mind az intézményrendszerben változhatnak.

\section{Programozás}

A fejlesztési stratégiák partnerségen alapuló kidolgozása, ezek megvalósitásának egyértelmủ célkitüzés rendszere, a fejlesztések egymásra épülése, időbeli uatemezése jelenti a programozást. A programozás elve az Unió regionális politikájában azt szolgálja, hogy ne egy-egy projektet (azaz egy-egy létesítményt, egy-egy akciót) támogassanak, hanem a területrendszer egészének, vagy annak meghatározott alrendszere fejlodését befolyásoló célkitűzéseket, vagy azok sorozatát. A fejlesztési stratégia tartalmazza a szereplők által kitüzött jövőbeli célok rendszerét, amiben megjelennek a magasabb területi egységek elképzelései is, f́gy a regionális és a nemzeti szintek. A területfejlesztési stratégia számára olyan célrendszert kell kidolgozni, amely „fent” a makrogazdaság prioritásaihoz kapcsolódik, míg „lent” a területi egység, így a régió fejlesztési elképzeléseit jeleníti meg.

A stratégia fejlesztési célkitüzésekböl áll, amikhez programok rendelhetök, mint a megvalósitás konkrét elemei, objektumai. A programok aztán materializálhatók, hiszen meghatározhatók például a létesítmények, az érintett szervezetek, mindezekhez hozzárendelhetők a megvalósítók (kivitelezők), a források (finanszírozók), s kimutatható, hogy milyen területi hatások, eredmények érhetők el a megvalósítással (monitoring). A programozás tehát egy célorientált folyamat, 
Rechnitzer János: A halogatott regionalizáció mint a területi politika sajátossága az átmenetben.

Tér és Társadalom, 15. 2001. 2. 3-24. p.

amiben a lépések szigorú sorozata követi egymást a célkitúzéstöl a megvalósitásig. Ez a rendszerezés és rendszerezettség lehetöséget nyújt a források alapos áttekintésére, koordinálására, azok időbeli ütemezésére, s a felhasználási szakaszhoz kapcsolódó ellenörzésekre.

A magyar regionális politikában jelentős lépések történtek a programozás elvének megvalósítására. Talán ennek az alapelvnek az érvényesülésénél adhatunk számot a legtöbb és leglátványosabb eredményekröl (Rechnitzer 1998b). A régiók többsége, a megyék mindegyike rendelkezik fejlesztési koncepcióval, megkezdödött ezek alapján a programok kidolgozása, a kistérségek nagy része fejlesztési koncepciót állított ossze, több vonatkozásban. Mindezek mellett megkezdỏdött a Strukturális Alapok fogadásának elökészítését szolgáló programozási rendszer kidolgozása regionális szinten, egyre tőbb nemzetközi program szerveződik. Mindemellett talán lényegesebb, mint az elözők - már látható az a fiatal és szakmailag megalapozott apparátus, amely regionális szinten képes, de egyben alkalmas is a programok vezénylésére.

A gondok persze még jócskán sorolhatók. Nem egyértelmü a területi szintek (ország, régió, megye, kistérség, település) egymásra épülése, a fejlesztési funkciók kapcsolata, megosztása, a tervezésben a szereplöi körök aktivizálása gyenge, különösen a gazdasági szféra, az ágazati és regionális programok összehangolása bizonytalan, a rendezési és fejlesztési tervek összeillesztése csak most kezdődik el, $\mathrm{s}$ mindezeknek a telepưlés szintú visszacsatolása nem következetes. Folyamatosan változnak a tervezési szempontok, a központi befolyás nem csökkent, hanem újabb és újabb formációkban jelenik meg. Inkább az ír, portugál modell jelei ismerhetök fel, mint a francia tervezési iskola már erősen regionalizálódó megújítási törekvései. A tervezés és programozás lendületes korszakát éli, két kérdésre kell minél elöbb választ adni. Az első, hogy milyen tényleges szerepe lesz a területi szintnek, $s$ döntően a régiónak a következö idöszakban a nemzeti stratégiák és azok programjainak kidolgozásában. S a második, ha lesz szerepe a régiónak, ehhez a források milyen garanciák mellett biztosítottak.

\section{Koncentráció és addicionálás}

Az Unió által nyújtott pénzügyi támogatást az adott országnak vagy területi egységnek, annak szereplőinek ki kell egészíteni saját hozzájárulás biztosításával, s egyben a támogatásokat azon régiókban kell felhasználni, ahol a legnagyobb az elmaradottság. A támogatásokat be kell illeszteni az Uniónak a tervidószakra meghatározott támogatási rendszerébe, annak elveinek érvényesítésével (Horváth 2001).

A fejlesztés pénzügyi erőforrásait az Unió teljes egészében nem biztosítja, ahhoz a területi szinteknek, vagy éppen a területfejlesztés szereplöinek hozzá kell járulnia, azaz saját forrásokra is szükség van, a támogatások kiegészítésre szorulnak. A regionális politika támogatási rendszere nem azt jelenti, hogy az adott ország területfejlesztési támogatási rendszerét az Európai Unió forrásai helyettesítik, hanem éppen fordítva: csupán azokat kiegészítik. A tagországoknak a terület- 
Rechnitzer János: A halogatott regionalizáció mint a területi politika sajátossága az átmenetben.

Tér és Társadalom, 15. 2001. 2. 3-24. p.

TÉT XV. évf. 2001 @ 2

A halogatott regionalizáció ...

19

fejlesztés támogatási rendszerét a korábbi szinten kell tartani, és általában elvárás, hogy az adott program finanszírozásának legalább a felét a tagország vállalja. A kevésbé fejlett országok esetében a hozzájárulás mértéke minimum $20 \%$-ot tesz ki.

A társfinanszírozás közvetlenül a tagországok költségvetését érinti, viszont a közösségi támogatások bevételként a régiókban jelennek meg. A nemzeti költségvetést terhelik tehát a támogatásokkal együtt jelentkező hozzájárulások, míg a bevételi' oldalt csak közvetetten és lényegében hosszabb távon befolyásolják (a GDP növekedés hatására meginduló adóbevételek csak évek múlva jelentkezhetnek). Mindez azt ösztönzi, hogy a helyi, térségi szereplök is gondoskodjanak a saját forrásaik felhasználásárobl, éppen azok koordinált hasznosítása érdekében.

A koncentráció és az addicionálás célja tehát kettős: összefogni (koncentrálni) az adottságokat, ugyanakkor ezzel is hozzájárulni a fejlesztési célkitúzés megvalósításához, mérsékelni egyúttal a párhuzamosságokat, csökkenteni a pazarlást, az elaprózottságot. A másik követelmény, hogy szükséges kialakítani olyan területi egységeket, amelyek azonos, vagy nagyon hasonló problémákkal rendelkeznek (pl. alacsony jövedelmi szint, magas munkanélküliség stb.). Ezzel elérhetök, hogy statisztikailag is meghatározhatók azok a területek, amelyek a legkedvezőtlenebb helyzetben vannak, ahová a forrásokat koncentrálni kell, egyben aztán regisztrálhatók a beavatkozások következményei, eredményei.

A hazai regionális politika talán egyik leggyengébb láncszeme az addicionalitás elvének alkalmazása. A területfejlesztésre fordítható közvetlen források mértéke jelentỏsen nem nőtt a GDP-hez mérten 1996-tól napjainkig, hiszen 1996-ban $0,174 \%, 1997$-ben $0,193 \%$ és 1998 -ban $0,216 \%$ volt. Az európai gyakorlatban ennek többszörösét, átlagosan a GDP 1,5-2,0\% közötti értékét forditják az országok közvetlenül területfejlesztésre (Horváth 1998). A források megyei szinten jelentkeznek, az elosztás elveit a megyei koncepciók és programok jelentik, a régiók egyelöre csak korlátozott és azonos összegủ fejlesztési forrásokhoz jutnak ${ }^{4}$. A kistérségek a megyei területfejlesztési tanácshoz fordulhatnak támogatásért, vagy más központi (ágazati) fejlesztési támogatásra, illetve egyes esetekben (PHARE régiók, határ menti helyzet) nemzetközi forrásokra pályázhattak, azonban látványos fejlesztéseket nem voltak képesek megvalósítani ${ }^{5}$.

A területfejlesztés szereplöinek forrás hozzájárulása döntően csak a saját fejlesztésekre vonatkozik, kimutatható viszont már egyes megyékben, hogy a támogatásokkal azok többszörösét érö (3-5-ször nagyobb) fejlesztéseket lehet indukálni, ami erősíti a decentralizált forráshasznosítás kedvezö voltát ( $A$ regionális szintü... 1999). 
Rechnitzer János: A halogatott regionalizáció mint a területi politika sajátossága az átmenetben.

Tér és Társadalom, 15. 2001. 2. 3-24. p.

20 Rechnitzer János

TÉT XV. évf. 2001

\section{TÁBLÁZAT}

A fejlesztés célú támogatások ${ }^{6}$ területi megoszlása (1996-1998, 1998. évi áron) (Regional Distribution of Regional Development Funds)

\begin{tabular}{|c|c|c|c|c|c|}
\hline \multirow{2}{*}{ Megye, régió } & \multicolumn{2}{|c|}{ Összes támogatás } & \multirow{2}{*}{$\begin{array}{l}\text { Aránya a GDP- } \\
\text { ben (1997, } \\
\text { országos átlag } \\
=100 \% \text { ) }\end{array}$} & \multirow{2}{*}{$\begin{array}{c}\text { Egy lakosra } \\
\text { jutó } \\
\text { támogatás } \\
\text { (ezer } \mathrm{Ft} \text { ) }\end{array}$} & \multirow{2}{*}{$\begin{array}{l}\text { A közvetlen } \\
\text { területfejlesztés } \\
\text { célú támogatás } \\
\text { aránya (\%) }\end{array}$} \\
\hline & Mrd Ft & $\%$ & & & \\
\hline Budapest & 63,9 & 11,8 & 34 & 34,8 & 0 \\
\hline Pest & 66,2 & 12,2 & 159 & 65 & 4,2 \\
\hline $\begin{array}{l}\text { Közép-Magyarország } \\
\text { összesen }\end{array}$ & 130,1 & 24,0 & 58 & 45,5 & 4,2 \\
\hline Fejér & 21,3 & 3,9 & 80 & 50,1 & 6,7 \\
\hline Komárom-Esztergom & 18,8 & 3,5 & 131 & 60,7 & 5,5 \\
\hline Veszprém & 20,7 & 3,8 & 128 & 55,3 & 7,6 \\
\hline Közép-Dunántúl összesen & 60,8 & 11,2 & 107 & 54,7 & 6,6 \\
\hline Györ-Moson-Sopron & 15,2 & 2,8 & 61 & 35,8 & 7,1 \\
\hline Vas & 10,8 & 2,0 & 66 & 40,4 & 7,2 \\
\hline Zala & 12,6 & 2,3 & 87 & 72,8 & 10,6 \\
\hline Nyugat-Dunántúl összesen & 38,6 & 7,1 & 70 & 38,6 & 8,3 \\
\hline Baranya & 21,1 & 3,9 & 121 & 52,3 & 11 \\
\hline Somogy & 18,8 & 3,5 & 150 & 56,6 & 10,7 \\
\hline Tolna & 13,9 & 2,6 & 124 & 56,6 & 9,3 \\
\hline Dél-Dunántúl összesen & 53,8 & 9,9 & 132 & 54,9 & 10,3 \\
\hline Borsod-A.Z. & 43,3 & 8,0 & 157 & 59 & 17,3 \\
\hline Heves & 23,8 & 4,4 & 189 & 73,6 & 8,3 \\
\hline Nógrád & 20,5 & 3,8 & 329 & 94,2 & 11,4 \\
\hline $\begin{array}{l}\text { Észak-Magyarország } \\
\text { összesen }\end{array}$ & 87,6 & 16,1 & 190 & 68,6 & 12,5 \\
\hline Hajdú-Bihar & 24,9 & 4,6 & 111 & 45,8 & 14,5 \\
\hline Jász-N.-Szolnok & 24,7 & 4,5 & 147 & 59,7 & 12,3 \\
\hline Szabolcs-Szatmár-B. & 50,3 & 9,3 & 285 & 88,1 & 13,4 \\
\hline Észak-Alföld összesen & 99,9 & 18,4 & 177 & 65,4 & 13,4 \\
\hline Bács-Kiskun & 27,9 & 5,1 & 132 & 52,2 & 13,4 \\
\hline Békés & 23,5 & 4,3 & 153 & 59,4 & 12,5 \\
\hline Csongrád & 20,9 & 3,8 & 103 & 49,9 & 12,2 \\
\hline Dél-Alföld összesen & 72,3 & 13,3 & 129 & 53,6 & 12,7 \\
\hline Ország összesen & 543,1 & 100,0 & 100 & 53,8 & 9,2 \\
\hline
\end{tabular}

Forrás: Jelentés a teruleti folyamatok... 2001. 
Rechnitzer János: A halogatott regionalizáció mint a területi politika sajátossága az átmenetben.

Tér és Társadalom, 15. 2001. 2. 3-24. p.

TÉT XV. évf. 2001 @ 2

A halogatott regionalizáció ...

21

A forráskoordináció az egyik neuralgikus pontja a regionális politikának. Az ágazati források területi szintủ összehangolása nem valósult $\mathrm{meg}^{7}$, nincs egyértelmüen meghatározva a különféle célelőirányzatoknál, alapoknál a területi elv, vagy területi preferencia. Történtek kezdeményezések a lopakodó decentralizációra ${ }^{8}$, de mindig a központi célokat érvényesítették a felhasználásnál, így dekoncentrált forrásként jöhetnek számba. A központi források, s egyben a pályázatok között az összehangolás sem országosan, sem területi szinten nem történt meg.

A regionális szint a területfejlesztési funkciókat csak átfogó finanszírozási decentralizációval oldhatja meg. Ennek modellje (Lados-Rechnitzer 2000) épülhet a központi források nagyobb hányadának leosztására (aminek első lépése az ágazatokkal való megállapodáson alapuló forrás-felhasználás, majd ennek alapján a regionális szinten létesített integrált fejlesztési alap létrehozása). A másik megoldás a központi adók megosztása, illetve a helyi adók egy bizonyos hányadának regionalizálása, azaz régió szinten történő új központosítás. Ebben az utóbbi modellben nagy szerepe van a minimális hozzájárulás elve müködtetésének, amely lényegében kritikus programfinanszírozást tartalmaz. A területfejlesztés regionális szereplöi kölcsönösen megegyeznek egy kritikus (nevezhetjük minimális) fejlesztési programban, amihez megnyerik a központi kormányzat támogatását, s mindezt egy tervszerzödésbe foglalják, minimálisan négy, maximálisan hat esztendö időtartamig. Ennek következtében mind regionális, mind országos szinten garantáltak a térségi fejlesztések eröforrásai, s az elképzelések múködésének terei (pl. intézményi bázisa, ellenörzési rendszere) biztosítottak lehetnek.

A magyar regionális politika az európai uniós csatlakozásig számos új feladat elött áll. A politika tudományos megalapozottsága magas szintü, abban tükrözỏdnek az európai területi folyamatok sajátosságai, a következő évtizedekben kijelölhetők a fejlődési irányok, az alkalmazkodás lehetséges modelljei. A területi menedzsment szakember-állománya egyre látványosabban szerveződik, kistérségi, megyei és regionális szinten egyre több és több felkészült, a területi folyamatok rendszerét értó ügyintézővel találkozhatunk, akik képesek és alkalmasak az elképzelések megvalósítására. A térségi szintek mindegyike rendelkezik fejlesztési koncepcióval, most kerülnek kidolgozásra ezek alapján a programok, azaz egy éven belül már a területi egységek ismerik a fejlesztés irányait, tisztában lesznek a megvalósítás föbb módjaival. A területfejlesztés szereplöi kezdik felismerni, hogy lokális és regionális dimenzióban is lehetőségek rejlenek fejlesztési céljaikhoz, így nagyobb összefogásra és együttmủködésre számíthatunk a jövőben.

Lassan, vontatottan halad viszont a decentralizáció, nem kap kellő támogatást az intézményrendszer határozottabb kiépítése, $\mathrm{s}$ a források területi koordinációja akadozik, ismét több központúvá vált a regionális politika irányítása, ami gyengíti az egyre dinamikusabban formálódó intézményrendszert és menedzsmentet. A gazdaságpolitika átfogó fejlesztési elképzeléseiben a regionális dimenzió csak áttételesen ismerhető fel. Az átmenet még nem fejeződött tehát be a regionális politikában, 
Rechnitzer János: A halogatott regionalizáció mint a területi politika sajátossága az átmenetben.

Tér és Társadalom, 15. 2001. 2. 3-24. p.

hiszen még nem erősödtek meg az új intézményrendszer elemei, a területi fejlesztések igencsak kitettek a központi kormányzat szándékának és elképzeléseinek. Viszont a magyar területi szerkezet és intézményrendszer az elkövetkező időben éppen a nagyobb politikai figyelemmel alkalmassá válhat az európai uniós támogatások hatékony fogadására, egyben döntő tényezője lesz az ország versenyképességének, s ezzel a gyorsított modernizációnak.

\section{Jegyzetek}

${ }^{1}$ A kistérségekben számos területfejlesztéssel foglalkozó település szintủ együttmükơdés létezik, ezek száma folyamatosan változik, a jelzett érték az önkormányzati társulåsokat mutatja (Jelentés... 2001)

${ }^{2}$ Nem a régiókhoz telepítik a Regionális Idegenforgalmi Bizottságokat (GM), a régiók nem kapnak beleszólást a kistérségi megbízottak kiválasztásába, s azok nem kapcsolódnak a regionális szervezethez (MEH), a SAPARD-program regionális szervezete szintén nem kerül a régióhoz (FVM) (1998-2001).

${ }^{3}$ A hazai regionális tudomány a régióra vonatkozóan már számos ismeretet feldolgozott. Ismerjük Ĺpusait és sajátosságait (Faragó 1994; Pálné Kovács 1999a), végigkövettük fejlödését a regionális politika magyarországi tơrténetén (Hajdú 2001), vizsgáltuk a lehatárolás kulönféle módjait (Bajmóczy-Kiss 1999; Szigeti 2001), elemzésre kerültek a regionalizációs törekvések és azok lehetséges hatásai (Kovács 1999, Szigeti 2000), bemutatásra kerültek a müködési zavarok (Zongor 1998; 1999), a lehetséges kơzigazgatási funkciók meghatározása is megtörtént (Pálné Kovács 1999b; Verebélyi 2000), söt a müködés finanszírozási modellje is kidolgozásra került (Lados-Rechnitzer 2000). Mindezeken túl még számos további alapos kutatás szưkséges, például a fejlesztés modelljeire, a régió gazdasági növekedési hatásaira, a szervezeti rendszerre, a menedzsmentre, az egyuittmúködés módjaira, a fejlesztések számbavételére.

${ }^{4}$ A regionális fejlesztési tanácsok kormányzati forrásokból (Vidékfejlesztési Célelőirányzat) 1998-ban 60 millió, 1999-ben 130 millió, 2000-ben 100 millió Ft-tal rendelkeztek a fejlesztések támogatására, ami eleve a koncepciók és a programok támogatására szolgált. 2001-től már 1,0-1,8 milliárd Ft decentralizált forrást nyertek el a régiók, bár ezek felhasználásában, ütemezésében a centralizációs reflexek múködnek, de megkezdhették saját fejlesztési programjaik kidolgozását.

${ }^{5}$ A tárcák közül kevesen ismerték fel a kistérségekben rejlő fejlesztési lehetőségeket, így számukra csak eseti jelleggel áll rendelkezésre pályázati forrás.

${ }^{6}$ Területi kiegyenlítést szolgáló támogatás, Címzett és Céltámogatás, Gazdaságfejlesztési Célelőirányzat Turisztikai Célelőirányzat, Munkaerö-piaci Alap, Agrártámogatások, Környezetvédelmi Alap Célfeladatai, Ưtfenntartási és Fejlesztési Célelöirányzat, Víziigyi Célelöirányzat.

${ }^{7}$ A borsodi integrált program a forráskoordinációt célozta meg, ebben jelentős sikerek mutathatók ki, de a modell országos kiterjesztése nem történt meg.

${ }^{8}$ Területi kiegyenlítést szolgáló támogatás, Címzett és Céltámogatás, Gazdaságfejlesztési Célelöirányzat Turisztikai Célelőirányzat, Munkaerő-piaci Alap.

\section{Irodalom}

Árva L.-Diczházi B. (1998) Globalizáció és a külföldi tỏkeberuházások Magyarországon. Budapest, Kairosz Kiadó-Növekedéskutató.

Bajmóczy P.-Kiss J. (1999) Megyék, régiók és központjaik, - Tér és Társadalom. 1-2. 31-51. o.

Enyedi Gy. (1996) Regionális folyamatok Magyarországon az átmenet idöszakában. Budapest, Hilscher Rezső Szociálpolitikai Egyesület.

Faragó L. (1994) Adalékok a területfejlesztéssel kapcsolatos fogalmak vitájához. - Tér és Társadalom. 3-4. 23-39. o.

Hajdú Z. (2001) Magyarország közigazgatás fóldrajza. Budapest-Pécs, Dialóg Campus Kiadó. 
Rechnitzer János: A halogatott regionalizáció mint a területi politika sajátossága az átmenetben.

Tér és Társadalom, 15. 2001. 2. 3-24. p.

A halogatott regionalizáció ...

Horváth Gy. (1998) Európai regionális politika. Budapest-Pécs, Dialóg Campus Kiadó.

Horváth Gy. (2001) Regionális támogatások az Európai Unióban. Budapest, Osiris.

Jelentés a területi folyamatok alakulásáról, a teriiletfejlesztési politika érvényesüléséröl és az Országos

Területfejlesztési Koncepció végrehajtásáról. (2001) Budapest, Magyar Köztársaság Kormánya.

Kovács T. (1999) Polémia a magyarországi régiókról? - Területi Statisztika. 2. 107-116. o.

Lados M.-Rechnitzer J. (2000) A regionális szintü teruletfejlesztés finanszírozási rendszerének megalapozása. - Horváth Gy,-Rechnitzer J. (szerk.) Magyarország területi szerkezete és folyamatai az ezredfordulón. Pécs, MTA RKK. 575-595. o.

Nárai M. (2000) Regionális identitás elemei a Nyugat-Dunántúlon. Györ, MTA RKK NYUTI. Kézirat.

Pálné Kovács I. (1999a) Régiók Magyarországa? - Info-Társadalomtudomány. 44. 31-41. o.

Pálné Kovács I. (1999b) Regionális politika és közigazgatás. Budapest-Pécs, Dialóg Campus Kiadó.

Rechnitzer J. (1998a) A privatizáció regionális összefüggései. Budapest, Kulturtrade Kiadó.

Rechnitzer J. (1998b) A területi stratégiák. Budapest-Pécs, Dialóg Campus Kiadó.

A regionalis fejlesztési koncepciók elemzése és értékelése a gazdaságfejlesztés szempontjából. (1999) MTA RKK Nyugat-magyarországi Tudományos Intézet Közleményei 98. sz. Győr, MTA RKK Nyugat-magyarországi Tudományos Intézet. Témavezető: Rechnitzer J.

A regionális szintü területfejlesztés finanszírozási rendszerének megalapozása. (1999) MTA RKK Nyugat-magyarországi Tudományos Intézet Közleményei 101. sz. Győr, MTA RKK Nyugatmagyarországi Tudományos Intézet. Témavezetỏ: Rechnitzer J.

A területfejlesztési koncepciók és programok összehasonlító értékelése. (2000) MTA RKK Nyugatmagyarországi Tudományos Intézet Közleményei 116. sz. Győr, MTA RKK Nyugat-magyarországi Tudományos Intézet. Témavezetö: Rechnitzer J.

Területfejlesztési Országgyúlési Beszámoló a teruleti folyamatok alakulásáról és a terủletfejlesztési politika érvényesủléséról (2000) Budapest, FVM Terïletfejlesztési Főosztály.

Szigeti E. (2000) A dekoncentrált államigazgatás térszerkezete. - Területi Statisztika. 5. 431-451. o.

Szigeti E. (2001) A regionális közigazgatás térstruktúra feltételei és lehetöségei. - Területi Statisztika. 2. $111-131.0$.

Szörényiné Kukorelli I. (1998) A Nyugat-Dunántúli Régió-régió? - Tér és Társadalom. 3. 51-75. o.

Verebélyi I. (2000) Önkormányzati rendszerváltás és modernizáció. - Magyar Közigazgatás. 9. 521528. o. és 10.577-587. o.

Zongor G. (1998) Kis magyar regionalizáció, avagy miért nem müködik az, aminek müködni kellene? Comitatus. Július-augusztus. 53-63. o.

Zongor G. (1999) Változatok a középszintre, avagy a magyar középszinttelenség. - Tér és Társadalom. 3. $45-57$. 0 .

\section{DEFERRED REGIONALISATION AS THE FEATURE OF REGIONAL POLICY IN THE TRANSITION PERIOD}

\section{JÁNOS RECHNITZER}

The study is aiming at presenting the most important characteristics of the Hungarian regional policy during the transition period. It defines the challenges the Hungarian regional development has to face before the accession, using the comparison of this political subsystem with the expectations of European Union's regional policy as a basis. The study pays attention to regionalisation, to the development of regions and to the factors assisting and hindering this process.

The study has three chapters. The first period, which finished in 1996, was the period of regional crisis management. Spatial impacts of political and economical system transformation were shocking. However foreign funds (Phare programme) played very important role in the management of regional crises, several measures were carried out to renew the economic structure especially to settle down foreign investments (western part of the country) and to diminish disadvantageous infrastructure situation (eastern part of the 
country). In the first period aims and methodologies of the traditional regional policy were dominant which were connected to modern market economy.

The second period (1996-1999) was characterised by the development of the institutional system of regional policy. The act on regional development has been passed, which provided the required frame for regional policy, and Regional Development Conception of Hungary defined the principals and directions of policy. Regions appeared only as a frame of principle, the counties and small regions formed the basic level of regional development. In the period of development of the institution system regional development received new impulse. Although planning started and management organisations were established, there were no available resources for development.

The third period started in 1999 with the modification of the act on regional development. This increased the role of regions. However in economic policy the focus moved to the central programme, the government representation in regional development was very week and feeble and the political elite did not committed itself to strong decentralisation so the conceptions of regionalisation were hindered. In this last period the elements of post-modern regional policy has already been appeared especially endogenous development initiatives, innovation systems building and local economy development.

In the second chapter of the study we compare the characteristics of transition with the principles of the European Union's regional policy. Although the principle of subsidiary got its way in regional policy, the real, operable regional level was not developed so the enforcement of regional interests were divided. The principle of partnership was only partly realised because of the restrained co-operation of regional development actors, which were not bottom-up initiated, but were initiated by the just forming regions for their management. Management organisations of regional development have been established but their cooperation with the development actors is only forming gradually. The principles of programming were adapted into Hungarian regional policy successfully. Analysis and planning of regional processes have been started and development programmes for different regional levels were elaborated. Resources for these development programmes have not been available yet, so the principle of additionality was only partly realised. In the previous years central programmes received determinant priority and they were connected to regional development conceptions only in indirect ways though we could not doubt their necessarity.

Transition has not finished in the Hungarian regional policy, which could be characterised by the dichotomy and continuos fight between centralisation and decentralisation. Development and preparation for European Union might and should have accelerated the regionalisation process with vast political support. The frames of this (institutional system, management, plans and programmes) have already been existed and are suitable for larger autonomy, which could open new areas of socio-economic development. 